University of Nebraska - Lincoln

DigitalCommons@University of Nebraska - Lincoln

USDA National Wildlife Research Center - Staff Publications
U.S. Department of Agriculture: Animal and Plant Health Inspection Service

July 2002

\title{
Seasonal marking efficacy of Dupont oil blue A dye on steam- rolled oat groat baits for valley pocket gophers
}

\author{
Craig A. Ramey \\ Animal and Plant Health Inspection Service, Wildlife Services, National Wildlife Research Center, US \\ Department of Agriculture \\ George H. Matschke \\ Animal and Plant Health Inspection Service, Wildlife Services, National Wildlife Research Center, US \\ Department of Agriculture \\ Richard M. Engeman \\ Animal and Plant Health Inspection Service, Wildlife Services, National Wildlife Research Center, US \\ Department of Agriculture, s_r100@yahoo.com
}

Follow this and additional works at: https://digitalcommons.unl.edu/icwdm_usdanwrc

Part of the Environmental Sciences Commons

Ramey, Craig A.; Matschke, George H.; and Engeman, Richard M., "Seasonal marking efficacy of Dupont oil blue A dye on steam-rolled oat groat baits for valley pocket gophers" (2002). USDA National Wildlife Research Center - Staff Publications. 490.

https://digitalcommons.unl.edu/icwdm_usdanwrc/490

This Article is brought to you for free and open access by the U.S. Department of Agriculture: Animal and Plant Health Inspection Service at DigitalCommons@University of Nebraska - Lincoln. It has been accepted for inclusion in USDA National Wildlife Research Center - Staff Publications by an authorized administrator of DigitalCommons@University of Nebraska - Lincoln. 


\title{
Seasonal marking efficacy of Dupont oil blue A dye on steam-rolled oat groat baits for valley pocket gophers
}

\author{
Craig A. Ramey ${ }^{2}$, George H. Matschke and Richard M. Engeman \\ Animal and Plant Health Inspection Service, Wildlife Services, National Wildlife \\ Research Center, US Department of Agriculture, 4101 LaPorte Avenue, Fort Collins, CO \\ 80521-2154, USA
}

Available online 8 November 2001.

\begin{abstract}
We examined if Valley pocket gophers (Thomomys bottae) exhibited a seasonal preference for consuming steamed-rolled oat (SRO) groat bait treated with 1.6\% Dupont oil blue A (fat-marking dye). Field tests were conducted in California alfalfa fields during winter, summer, and fall, and in walnut orchards during winter and summer. Five treatment units (TUs) were established each with $\sim 60$ burrows for each season and habitat studied during 1997-1999. SRO groat marker bait (4 g) was placed inside each active burrow. All bait sites were re-opened about $96 \mathrm{~h}$ later and examined for the presence (all or some) or absence of bait. The average bait site disturbance after 4 days of baiting was $78.2 \%$. Traps were used to capture gophers up to 5 days after baiting. Valley pocket gophers $(n=744)$ were examined for the presence of blue dye in their cheek pouches, skin/fur, and fat. We expected that if gophers moved the bait, their cheek pouches and fur would be marked; if they consumed bait, their fat would be marked. In alfalfa, $54.2 \%, 46.8 \%$, and $65.7 \%$, of gophers were marked (trapping on days $5-9$ ) by blue dye in one or more of their cheek pouches, skin, fur, or subcutaneous fat in the winter, summer, or fall, respectively. In orchards, $57.1 \%$ of gophers were marked in winter and $53.4 \%$ in summer. Of those that were marked, all (100\%) had their fat dyed blue, followed by skin/fur (34.4\% males: $43.7 \%$ females) and cheek pouches $(5.7 \%$ males: $10.1 \%$ females). ANOVA results indicated no difference in seasonal marking efficacy in either alfalfa or orchards $(F=3.59, P=0.0598$ and $F=0.12, P=0.7384$, respectively). The usefulness of $1.6 \%$ Dupont oil blue A dye as a marking agent for Valley pocket gophers was not demonstrated overall or for any season in either habitat. Therefore, a better marker for this gopher is needed. Some factors that may have influenced these results were discussed including: (1) baiting methodology ( $\sim 66 \%$ of the bait sites were devoid of bait at the end of the study), (2) species specific dye properties, (3) bait acceptance (i.e. aversion to the dye), or (4) availability of alternative foods.
\end{abstract}

Author Keywords: Pocket gophers; Marker; Dupont oil blue A

Published in International Biodeterioration \& Biodegradation Volume 49, Issues 2-3 , 2002, Pages 163-167 


\title{
Seasonal marking efficacy of Dupont oil blue A dye on steam-rolled oat groat baits for valley pocket gophers
}

\author{
Craig A. Ramey *, George H. Matschke, Richard M. Engeman \\ Animal and Plant Health Inspection Service. Wildife Sertices, National Wildife Research Center, US Department of Aariculture, 4101 LaPorte \\ Acente. Fort Collins. CO 80521-2154. USA
}

\begin{abstract}
We examined if Vallcy pocket gophers (Thomomis bottce) exhibited a seasonal preference for consuming steamed-rolled oat (SRO) groat bait treated with 1.6\% Dupont oil blue A (fat-marking dye). Field tests were conducted in California alfalfa fields during winter, summer, and fall, and in walnut orchards during winter and summer. Five treatment units (TUs) were established each with $\sim 60$ burrows for each season and habitat studied during 1997-1999. SRO groat marker bait (4 g) was placed inside each active burrow. All bait sites were re-opened about $96 \mathrm{~h}$ later and examined for the presence (all or somc) or absence of bait. The average bait sitc disturbance after 4 days of baiting was $78.2 \%$. Traps were used to capture gophers up to 5 days after baiting. Valley pocket gophers $(n=744)$ were examined for the presence of blue dye in their cheek pouches, skin/fur, and fat. We expected that if gophers moved the bait, their check pouches and fur would be marked; if they consumed bait, their fat would be marked. In alfalfa, 54.2\%, 46.8\%, and $65.7 \%$, of gophers were marked (trapping on days 5-9) by blue dye in one or more of their cheek pouches, skin, fur, or subcutaneous fat in the winter, summer, or fall, respectively. In orchards, $57.1 \%$ of gophers were marked in winter and $53.4 \%$ in summer. Of those that were marked, all ( $100 \%$ ) had their fat dyed blue, followed by skin/fur (34.4\% males : $43.7 \%$ females) and cheek pouches (5.7\% males : $10.1 \%$ females). ANOVA results indicated no difference in seasonal marking efficacy in either alfalfa or orchards $(F=3.59, P=0.0598$ and $F=0.12, P=0.7384$, respectively). The usefulness of 1.6\% Dupont oil blue A dye as a marking agent for Valley pocket gophers was not demonstrated overall or for any season in either habitat. Therefore, a better marker for this gopher is needed. Some factors that may have influenced these results were discussed including: (1) baiting methodology ( $\sim 66 \%$ of the bait sites were devoid of bait at the end of the study), (2) species specific dye properties, (3) bait acceptance (i.e. aversion to the dye), or (4) availability of alternative foods. (C) 2002 Elsevier Science Ltd. All rights reserved.
\end{abstract}

Keywords: Pocket gophers; Marker; Dupont oil blue A

\section{Introduction}

Pocket gophers (Thomomy's sp.) cause major damage to irrigated alfalfa fields in California (Lee et al., 1990). During the late 1980s, the California Department of Food and Agriculture (CDFA) received reports from cooperators in the Sacramento Valley that strychnine alkaloid grain baits had become less effective for controlling this genus (J. Clark, CDFA, pers. commun.). Howard et al. (1968) and Marsh and Howard (1978) explained that some pocket gophers may not develop the typical bait/poison shyness that other rodents demonstrate after ingesting a sublethal dose of the pesticide, but they may develop an acquired physiological tolerance to strychnine after ingesting a series of sublethal doses (Lee et al., 1990). Consequently, CDFA sought to

\footnotetext{
${ }^{*}$ Corresponding author.
}

improve their rodenticide formulations and baiting methodologies.

A variety of markers including dyes, inert particles, tetracycline, blood markers, and radio-isotopes have been used to study free-ranging mammals and birds to help understand their: (1) population dynamics, (2) non-target exposure to control techniques, and (3) bait acceptance (Savarie et al., 1992). Some markers used to evaluate bait acceptance include rhodamine B in black-tailed jackrabbits (Lepus californicus) (Evans and Griffith, 1973), dimethylchlorotetracycline in Norway rats (Rattus norregicus) (Nass et al., 1971), and metallic flake particle markers in Norway rats (Fall and Johns, 1988). Linhart et al. (1993) and Creekmore et al. (1994) used Dupont oil blue A dye (DuPont Chemicals, Wilmington, DE, USA) to evaluate oral rabies baits in Indian mongooses (Herpestes auropunctatus) and (H. javanicus), respectively. They found it was visible in both abdominal fat and lower intestines, and 
they concluded that it was an effective short-term marker $(<1$ day $)$.

In laboratory studies, northern pocket gophers ( $T$. talpoides) were marked by DuPont oil blue A, and the blue dye was visible in cheek pouches and skin fur (externally) and in adipose tissues (internally) (P. Savarie, NWRC. pers. commun.). It seemed to demonstrate each gopher's propensity to move and/or ingest bait (bait acceptance). Four concentrations $(0.2 \%, 0.4 \%, 0.8 \%$, or $1.6 \%)$ were used on steam rolled oat (SRO) groat bait in a laboratory study to determine its marking effectiveness on pocket gophers. Only the $1.6 \%$ concentration effectively marked $100 \%(n=13)$ of the northern pocket gophers tested; consumption ranged from 0.03 to $4.07 \mathrm{~g} /$ day (G. Matschke et al., NWRC, unpublished Report No. 289, 1993). To further evaluate this marker on SRO groat bait, a larger laboratory study was conducted with the same species; consumption averaged $2.48 \mathrm{~g} /$ day $(n=38)$, with intake ranging from 0.17 to $4.24 \mathrm{~g}$. Dyed fat was detected in 36 of $38(95 \%)$ of the gophers at 5 days after ingesting the marker (G. Matschke et al., NWRC, unpublished Report No. 317, 1994).

A field trial with $1.6 \%$ DuPont oil blue A showed that northern pocket gophers disturbed 32 of $37(86.5 \%)$ the bait sites, but they consumed much less marker bait than placebo bait. Only $35 \%$ of 20 captured pocket gophers during the alfalfa growing season had blue-dyed fat (G. Matschke et al., NWRC, unpublished Report No. 310 Part I, 1994). It was hypothesized that the low consumption of marker bait was due to a scasonal preference for the growing alfalfa roots and tubers. Two field trials conducted in the late fall when alfalfa was dormant seemed to support this hypothesis, with increased marking rates of $87.5 \%$ and $96.0 \%$ (G. Matschke et al., NWRC, unpublished Report No. 310 Parts II and III, 1996, 1997, respectively).

In this field study, we investigated the addition of DuPont oil blue $A$ to CDFA's non-toxic base bait to determine whether Valley pocket gophers exhibit a seasonal marking efficacy.

\section{Materials and methods}

\subsection{Study sites}

The two study sites (alfalfa and orchards) were located within a 10 mile radius of Visalia, Tulare County, California. Fifteen treatment units (TUs) were placed in flood-irrigated alfalfa (Medicago satica) fields, and 10 TUs were placed in flood-irrigated walnut (Juglans californica) orchards (Table 1). In the latter habitat, most of the surface vegetation had been removed to reduce competition for nutrients and to increase harvest yields. Topography for all TUs was consistent, with each site having $\leqslant 5 \%$ slope. The average elevation was $101 \mathrm{~m}$ above sea level. Climatological data were obtained from the National Weather Service station located at Visalia, California. Temperature and precipitation
Table 1

Description of treatment unit (TU) borrows baited for gophers by season in altalfa and orchards

\begin{tabular}{|c|c|c|c|c|c|c|}
\hline $\begin{array}{l}\text { Season } \\
\& \text { crop }\end{array}$ & Year & TU & $\begin{array}{l}\text { Size } \\
\text { (ha) }\end{array}$ & $\begin{array}{l}\text { Active } \\
\text { burrows }\end{array}$ & $\begin{array}{l}\text { Baiting } \\
\text { date }\end{array}$ & $\begin{array}{l}\text { Amount of } \\
\text { bait }(\mathrm{kg})\end{array}$ \\
\hline \multirow{5}{*}{$\begin{array}{l}\text { Winter } \\
\text { alfalfa }\end{array}$} & \multirow[t]{5}{*}{1999} & 26 & 0.91 & 60 & 112 & 0.61 \\
\hline & & 27 & 0.98 & 60 & 117 & 0.88 \\
\hline & & 28 & 0.65 & 60 & $1: 18$ & 0.57 \\
\hline & & 29 & 0.46 & 60 & 122 & 0.97 \\
\hline & & 30 & 1.48 & 60 & $1: 30$ & 0.84 \\
\hline \multirow{5}{*}{$\begin{array}{l}\text { Summer } \\
\text { alfalfa }\end{array}$} & \multirow[t]{3}{*}{1997} & 1 & 2.68 & 52 & $7: 14$ & 0.51 \\
\hline & & 2 & 5.70 & 46 & $7: 16$ & 0.48 \\
\hline & & 3 & 4.10 & 34 & 7,22 & 0.29 \\
\hline & \multirow[t]{2}{*}{1998} & 15 & 4.84 & 60 & $7 \% 9$ & 0.36 \\
\hline & & 16 & 10.51 & 60 & $7: 9$ & 0.41 \\
\hline \multirow{5}{*}{$\begin{array}{l}\text { Fall } \\
\text { alfalfa }\end{array}$} & \multirow[t]{5}{*}{1998} & 20 & 10.44 & 60 & $9: 23$ & 0.32 \\
\hline & & 21 & 4.77 & 60 & 9225 & 0.30 \\
\hline & & 22 & 9.47 & 60 & 930 & 0.32 \\
\hline & & 23 & 2.30 & 60 & $10 / 7$ & 0.39 \\
\hline & & 24 & 4.80 & 60 & $10 / 9$ & 0.39 \\
\hline \multirow{5}{*}{$\begin{array}{l}\text { Winter } \\
\text { orchard }\end{array}$} & \multirow[t]{4}{*}{1998} & 6 & 2.20 & 60 & $1 / 24$ & 0.57 \\
\hline & & 7 & 1.57 & 60 & $1 / 28$ & 0.52 \\
\hline & & 8 & 1.57 & 60 & $2 / 15$ & 0.34 \\
\hline & & 9 & 3.48 & 60 & $2 / 25$ & 0.45 \\
\hline & 1999 & 25 & 0.88 & 60 & $1 / 10$ & 0.41 \\
\hline \multirow{5}{*}{$\begin{array}{l}\text { Summer } \\
\text { orchard }\end{array}$} & \multirow[t]{2}{*}{1997} & 4 & 1.30 & 62 & $7 / 23$ & 1.04 \\
\hline & & 5 & 2.00 & 45 & $7 / 24$ & 0.57 \\
\hline & \multirow[t]{3}{*}{1998} & 17 & 2.20 & 60 & $7 / 13$ & 0.42 \\
\hline & & 18 & 4.84 & 60 & $7 / 17$ & 0.36 \\
\hline & & 19 & 3.18 & 60 & $7 / 18$ & 0.34 \\
\hline
\end{tabular}

varied depending on the month and year ( $24 \mathrm{~h}$ maximum range $3.9-39.4^{\circ} \mathrm{C}$ and minimum range $1.7-27.8^{\circ} \mathrm{C}$; total precipitation ranged from $0-11.7 \mathrm{~cm}$ per month).

\subsection{DuPont oil blue a baits}

Two separate batches of SRO groat bait were used in this study during 1997-1999 because initial estimates of usage were not sufficient for the entire study. The first batch, weighing $11.5 \mathrm{~kg}$ and the second weighing $4.8 \mathrm{~kg}$, were formulated on July 3, 1997 and on November 11, 1998, respectively. Both batches were mixed using the same proportions: (1) $97.15 \%$ steamed-rolled oat groats, (2) $1.60 \%$ DuPont oil blue A, and (3) $1.25 \%$ Alcolec S (lecithin binder). After mixing, the bait was placed in plastic bags and stored at $-18^{\circ} \mathrm{C}$ or colder until used.

\subsection{Bait application}

Valley pocket gopher burrows were baited during three seasons of the year (winter, summer, and fall) in alfalfa and two seasons (summer and winter) in orchards. The size and shape of each TU was dependent upon the number and distribution of gopher mounds. Our goal was to locate 60 fresh 
mounds within each TU and establish 5 TUs per season. Each fresh mound was marked with a single colored wire flag numbered consecutively. Individual TUs were separated by a buffer of at least $30.5 \mathrm{~m}$. In alfalfa fields, the majority of gopher activity was concentrated on the dirt berms constructed for irrigation. Likewise, gopher activity in orchards was found mainly on the berms.

The subterranean tunnel systems of gophers were located by probing near the center of each fresh fan-shaped mound. Some burrow openings contained a characteristic round earthen plug. Once a tunnel was found, each site was hand baited with $4 \mathrm{~g}$ of bait. If a gopher tunnel ran in more than one direction, each direction was baited. All bait was placed in a pilc as far back in the tunnel as the measuring spoon would allow $(\sim 10 \mathrm{~cm})$. Because pocket gophers never leave their burrows open for long, one picce of newspaper was immediately placed over each opening and covered with dirt to minimize human disturbance. Four days $(96 \mathrm{~h})$ after bait placement, all flagged sites were re-examined. The newspaper was carefully removed and each tunnel was re-opened and examined for bait site disturbance by recording all bait present (AP), some bait present (SP), or no bait present (NP). All bait was weighed pretreatment and posttreatment. Over 1400 bait sites were constructed in alfalfa (531 winter, 387 summer, and 499 fall) and 993 bait sites in orchards ( 516 winter and 477 summer).

Immediately after examining bait sites, traps (either Macabee traps, cinch traps, or Black Hole traps) were set in each of the re-opened tunnels. If a tumnel was plugged so tightly that it could not be re-opened, a new opening was prepared as near to the old one as possible and a trap placed there. Traps were checked morning and evening on each TU and left in place for a total of 5 days. Carcasses of all captured gophers were placed in individual plastic bags, appropriately labeled, and recorded. Bagged carcasses were frozen until examined for the presence of DuPont oil blue A dye. Six gophers were captured about $1 \mathrm{~km}$ away from the study area and served as controls.

Body weight and sex were recorded before each gopher was examined externally for the presence of bluc coloration on the nose, feet, tail, ears, skin, and fur. Cheek pouches were also examined for bluc coloration and presence of dyed bait. Then, each gopher was examined for blue coloration in the subcutancous fat around its back, shoulders, hips, neck, tail, and vital organs including the heart.

Five TUs were established in alfalfa during winter, summer, and fall, and they averaged $0.90,5.57$, and 6.36 ha, respectively. Winter TUs were baited in January 1999 with an average of $0.77 \mathrm{~kg}$ of bait. Two summers were needed to establish the summer TUs, and they were baited in July 1997 (3 TUs) and 1998 (2 TUs) with an average of $0.41 \mathrm{~kg}$ of bait. Fall 1998 TUs were baited in September and October with an average of $0.34 \mathrm{~kg}$ of bait.

In orchards, five TUs were established in winter and summer. Winter TUs averaged 1.94 ha and were baited in January and February 1998 (4 TUs) and January 1999 (1 TU)
Table 2

Valley pocket gopher bait site disturbance after four days of baiting for each treatment unit (TU)

\begin{tabular}{|c|c|c|c|c|c|}
\hline $\begin{array}{l}\text { Season } \\
\& \text { crop }\end{array}$ & Year & $\mathrm{TU}$ & $\begin{array}{l}\text { All bait } \\
\text { present }\end{array}$ & $\begin{array}{l}\text { Some bait present } \\
\& \text { no bait present }\end{array}$ & $\begin{array}{l}\text { Bait distur- } \\
\text { bance }(\%)\end{array}$ \\
\hline $\begin{array}{l}\text { Winter } \\
\text { alfalfa }\end{array}$ & 1999 & $\begin{array}{l}26 \\
27 \\
28 \\
29 \\
30\end{array}$ & $\begin{array}{l}17 \\
13 \\
20 \\
26 \\
18\end{array}$ & $\begin{array}{l}79 \\
94 \\
93 \\
82 \\
89\end{array}$ & $\begin{array}{l}82.3 \\
87.9 \\
82.3 \\
75.9 \\
83.2\end{array}$ \\
\hline $\begin{array}{l}\text { Summer } \\
\text { alfalfa }\end{array}$ & 1998 & $\begin{array}{r}1 \\
2 \\
3 \\
15 \\
16\end{array}$ & $\begin{array}{l}15 \\
14 \\
19 \\
19 \\
14\end{array}$ & $\begin{array}{l}48 \\
46 \\
41 \\
82 \\
89\end{array}$ & $\begin{array}{l}76.2 \\
76.7 \\
68.3 \\
81.2 \\
86.4\end{array}$ \\
\hline $\begin{array}{l}\text { Fall } \\
\text { alfalfa }\end{array}$ & 1998 & $\begin{array}{l}20 \\
21 \\
22 \\
23 \\
24\end{array}$ & $\begin{array}{l}15 \\
22 \\
20 \\
12 \\
12\end{array}$ & $\begin{array}{l}84 \\
74 \\
77 \\
91 \\
85\end{array}$ & $\begin{array}{l}84.8 \\
77.1 \\
79.4 \\
88.3 \\
87.6\end{array}$ \\
\hline $\begin{array}{l}\text { Winter } \\
\text { orchard }\end{array}$ & 1999 & $\begin{array}{r}6 \\
7 \\
8 \\
9 \\
25\end{array}$ & $\begin{array}{l}20 \\
46 \\
29 \\
20 \\
17\end{array}$ & $\begin{array}{l}90 \\
65 \\
69 \\
78 \\
82\end{array}$ & $\begin{array}{l}81.8 \\
58.6 \\
70.4 \\
79.6 \\
82.8\end{array}$ \\
\hline $\begin{array}{l}\text { Summer } \\
\text { orchard }\end{array}$ & $\begin{array}{l}1997 \\
1998\end{array}$ & $\begin{array}{r}4 \\
5 \\
17 \\
18 \\
19\end{array}$ & $\begin{array}{l}60 \\
27 \\
14 \\
20 \\
15\end{array}$ & $\begin{array}{l}50 \\
46 \\
84 \\
74 \\
87\end{array}$ & $\begin{array}{l}45.4 \\
63.0 \\
85.7 \\
78.7 \\
85.3\end{array}$ \\
\hline
\end{tabular}

with an average of $0.46 \mathrm{~kg}$ of bait. The summer TUs averaged 2.70 ha and were baited in July 1997 (2 TUs) and July 1998 (3 TUs) with an average of $0.55 \mathrm{~kg}$ of bait (Table 1 ).

\section{Results}

\subsection{Bait site disturbance}

Bait site disturbance (i.e. percent of bait sites with all or some bait missing versus all bait present after 4 days of baiting) was $82.3,79.1$, and 83.5 for winter, summer, and fall alfalfa, respectively. Bait site disturbance in orchards was less in both winter (74.4) and summer (71.5) (Table 2). The average bait site disturbance was $78.2 \%$.

\subsection{Seasonal marking}

Fat was the best indicator of bait consumption using SRO groats treated with $1.6 \%$ DuPont oil blue $\mathrm{A}$, because all of the marked animals had blue-dyed fat whereas only some of these were externally marked (cheek pouches < skin/fur). However, the overall percentage of marked gophers was only $56.6 \%$ of those captured. Regardless of habitat type, 
Table 3

Seasonal variation in gopher captures and dye patterns from treatment units (TU) $)^{a}$

\begin{tabular}{|c|c|c|c|c|c|c|c|}
\hline \multirow{2}{*}{$\begin{array}{l}\text { Season } \\
\& \text { crop }\end{array}$} & \multirow{2}{*}{ Year } & \multirow{2}{*}{ Sex } & \multirow{2}{*}{$\begin{array}{l}\text { Total } \\
\text { captures }\end{array}$} & \multirow{2}{*}{$\begin{array}{l}\text { No. percent } \\
\text { marked }\end{array}$} & \multicolumn{3}{|c|}{ Dyed (No. percent of marked animals) } \\
\hline & & & & & Cheek pouch & Skin fur & Fat \\
\hline \multirow{3}{*}{$\begin{array}{l}\text { Winter } \\
\text { alfalfa }\end{array}$} & \multirow[t]{3}{*}{1999} & $F^{1}$ & 134 & $75: 56.0$ & $15: 20.0$ & $41: 54.7$ & $75: 100$ \\
\hline & & $\mathrm{M}^{2}$ & 69 & 3550.7 & $3: 8.6$ & 11.31 .4 & $35: 100$ \\
\hline & & $\mathrm{F} \& \mathrm{M}$ & 203 & 110.54 .2 & $18 \cdot 16.4$ & $52 \cdot 47.3$ & 110100 \\
\hline \multirow{9}{*}{$\begin{array}{l}\text { Summer } \\
\text { alfalfa }\end{array}$} & \multirow[t]{3}{*}{1997} & $\mathrm{~F}$ & 25 & 1144.0 & $1 / 9.1$ & $5: 45.5$ & $11 / 100$ \\
\hline & & $\mathrm{M}$ & 6 & 5883.3 & 00 & $1 / 20.0$ & $5 / 100$ \\
\hline & & $\mathrm{F} \& \mathrm{M}$ & 31 & $16 / 51.6$ & 16.3 & $6: 37.5$ & 16100 \\
\hline & \multirow[t]{3}{*}{1998} & $\mathrm{~F}$ & 30 & $11 / 36.7$ & $0 / 0$ & 763.6 & 11100 \\
\hline & & M & 16 & $9 / 56.3$ & $0 / 0$ & 555.6 & $9 / 100$ \\
\hline & & $\mathrm{F} \& \mathrm{M}$ & 46 & $20 / 43.5$ & $0 / 0$ & $12 / 60$ & $20 / 100$ \\
\hline & \multirow[t]{3}{*}{$97 \& 98$} & $\mathrm{~F}$ & 55 & $22 / 40.0$ & $1 / 4.6$ & $12 / 54.6$ & $22 / 100$ \\
\hline & & $\mathrm{M}$ & 22 & $14 / 63.6$ & $0 / 0$ & $6 / 42.9$ & $14 / 100$ \\
\hline & & $F \& M$ & 77 & $36 / 46.8$ & $1 / 2.8$ & $18 / 50.0$ & $36 / 100$ \\
\hline \multirow{3}{*}{$\begin{array}{l}\text { Fall } \\
\text { alfalfa }\end{array}$} & \multirow[t]{3}{*}{1998} & $\mathrm{~F}$ & 114 & $76 / 66.7$ & $12 / 15.8$ & $34 / 44.7$ & $76 / 100$ \\
\hline & & $\mathrm{M}$ & 55 & $35 / 63.6$ & $1 / 2.9$ & $16 / 45.7$ & $35 / 100$ \\
\hline & & $\mathrm{F} \& \mathrm{M}$ & 169 & $111 / 65.7$ & $13 / 11.7$ & $50 / 45.0$ & $111 / 100$ \\
\hline \multirow{3}{*}{$\begin{array}{l}\text { Winter } \\
\text { orchards }\end{array}$} & \multirow[t]{3}{*}{1998} & $\mathrm{~F}$ & 107 & $57 / 53.3$ & $0 / 0$ & $17 / 29.8$ & $57 / 100$ \\
\hline & & $\mathrm{M}$ & 70 & $44 / 62.9$ & $4 / 9.1$ & $10 / 22.7$ & $44 / 100$ \\
\hline & & $F \& M$ & 177 & $101 / 57.1$ & $4 / 4.0$ & $27 / 26.7$ & $101 / 100$ \\
\hline \multirow{3}{*}{$\begin{array}{l}\text { Summer } \\
\text { orchards }\end{array}$} & & $\mathrm{F}$ & 92 & $48 / 52.2$ & $3 / 6.3$ & $23 / 47.9$ & $48 / 100$ \\
\hline & & $\mathrm{M}$ & 26 & $15 / 57.7$ & $1 / 6.7$ & $5 / 33.3$ & $15 / 100$ \\
\hline & & $F \& M$ & 118 & $63 / 53.4$ & $4 / 6.4$ & $28 / 44.4$ & $63 / 100$ \\
\hline
\end{tabular}

${ }^{\mathrm{a}} \mathrm{F}^{\prime}=$ Females and $\mathrm{M}^{2}=$ Males.

$51.0 \%$ of gophers were marked during summer, $65.7 \%$ during fall, and $55.6 \%$ during winter. In alfalfa, $54.2 \%, 46.8 \%$, and $65.7 \%$ were marked during the winter, summer, or fall, respectively (Table 3 ). Of the gophers not marked, $87 \%$, $66 \%$, and $74 \%$ were taken from sites where all the bait had been removed during the winter, summer, or fall, respectively. Results from baiting in orchards indicated $57.1 \%$ of the gophers were marked during the winter and $53.4 \%$ during summer (Table 3). Of the gophers not marked, $71.0 \%$ were taken from sites devoid of all bait during winter and $80 \%$ during summer. ANOVA results indicated no difference in seasonal marking efficacy in either alfalfa or orchards $(F=3.59, P=0.0598$ and $F=0.12, P=0.7384$, respectively).

\subsection{Marking of gophers by sex}

In alfalfa, $48.3 \%$ of the females and $50.0 \%$ of the males were marked; in orchards, $52.8 \%$ of the females and $61.5 \%$ of the males were marked. Of those that were marked, all $(100 \%)$ had dyed fat, followed by skin/fur (43.7\% females : $34.4 \%$ males) and cheek pouches ( $10.1 \%$ females: $5.7 \%$ males). Typically, females had blue-dyed fat around their bladder; males tended to have blue-dyed fat around their testicles.

\subsection{Non-target trapping hazard}

Only 3 non-target mammals were captured and none were marked. Two were California moles (Scrapanus latimanus) that were captured in kill traps in different orchard TUs. The third animal was a long-tailed weasel (Mustela frenata) which was captured in alfalfa and released unharmed.

\section{Discussion}

Several factors may have led to these marking results. First, with our baiting methodology over $66 \%$ of the bait sites were devoid of the bait after 4 days. If these burrows held multiple pocket gophers, some of the gophers captured may not have come in contact with the bait. Multiple gopher captures occurred at $105(4.4 \%)$ bait sites, with $90(42.4 \%)$ gophers marked and $123(57.7 \%)$ not marked. Therefore, having either more bait at each site or more bait sites would probably not have significantly increased the number of marked gophers.

Second, DuPont oil blue A may not have had the same marker characteristics with the Valley pocket gophers as it did with the northern pocket gopher. It may be more species specific than we had anticipated. In a laboratory report to evaluate the short-term longevity of the marker in fat in the northern pocket gopher at 2, 4, 7, and 14 days after 
ingestion, $100 \%, 97 \%, 80 \%$, and $55 \%$ were marked (each $n=20$ ), respectively ( $\mathrm{G}$. Matschke et al., NWRC, unpublished Report No. PS-108, 1999). By comparison in the current study, the $56.6 \%$ overall marker success at days 5-9 from the day of baiting was unexpected low, even with a high of $65.7 \%$ in fall alfalfa. Therefore, the use of other dyes may produce better marker results. For example, rhodamine $\mathrm{B}$ has been used to mark black-tailed jackrabbits for at least 6 weeks (Evans and Griffith, 1973).

Third, the marker dye must be palatable and well accepted. Information concerning this criterion is limited. Bait aversion to baits formulated with $1.6 \%$ DuPont oil blue $\mathrm{A}$ was observed in laboratory tests with the northern pocket gopher (Matschke et al., 1999. NWRC unpublished Report No. PS-108). They reported consumption of the maker bait was significantly lower than undyed bait $(P=0.0017)$. In field work conducted later, they stated bait aversion to DuPont oil blue A may be overcome by the baiting methods used in the present study (Matschke et al., 1997, Part III, NWRC unpublished Report No. 310). Therefore, we expected similar marking results with the Valley pocket gopher to theirs with the northern pocket gopher. However, we believe our lower than expected marker results may have demonstrated a possible bait aversion to comsumption by gophers versus the movement of bait as measured by bait site disturbance of $\sim 80 \%$. Before any additional field studies are conducted with this species, this question should be investigated. Also, we expected the external marking data from cheek pouches would support our results from the bait site disturbance data. It did not, probably because the use of external markers was more transitory than anticipated.

Fourth, did they prefer natural forage to the SRO marker baits? Some data were obtained about this factor by investigating the possible seasonal differences in the marking of gophers. We assumed that it was more plausible for gophers in summer or fall to prefer natural forage to baits and less likely for gophers in winter when alternative forage is dormant. Because there were no seasonal marking differences, we believe some factor other than a preference for natural forage is a more likely an explanation of these results.

\section{Acknowledgements}

This study was supported with funds from the California Vertebrate Pest Control Research Advisory Committee through a Cooperative Agreement between the CDFA and USDA/APHIS. We especially thank Nick Condos and staff of the California Department of Agriculture, Aimee Noble, and personnel of the Tulare County Department of Agriculture, and our co-workers for the many hours spent in the ficld in all types of weather. Geraldine McCann, Ken Tope, Jean Bourassa, and Bill Stewart of the National Wildlife Research Center spent many hours of preparation, field work, and assistance in this investigation; Kathleen Fagerstone, Michael Fall, Peter Savarie, John Eisemann, Brett Petersen, Steve Shumake, and Ray Sterner provided very helpful reviews of earlier drafts of the manuscript.

\section{References}

Creekmore, T.E., Linhart, S.B., Corn, J.L., Whitney, M.D., Synder, B.D.. Nettles, V.F., 1994. Field evaluations of baits and baiting strategics for delivering oral vaccine to mongooses in Antigua. West Indies. Journal of Wildlife Diseases 30 (4), 497--505.

Fvans, J., Griffith, R.E., 1973. A fluorescent tracer and marker for animal studies. Journal of Wildlife Management 37, 73-81.

Fall, M.W.. Johns, B.E., 1988. Metallic flake particle markers for determining the feeding behavior of rats at bait points. In: Shumake. S.A., Bullard, R.W. (Eds.), Vertebrate Pest Control and Management Materials, Vol. 5. ASTM STP 974 American Society for Testing and Materials, Philadelphia, pp. 128133.

Howard, W.E., Palmateer, S.D., Nachman, M., 1968. Aversion to strychnine sulfate by Norway rats, roof rats and pocket gophers. Toxicology and Applied Pharmacology 12, 229241.

Lee, L.L., Howard, W.E., Marsh, R.E., 1990. Acquired strychnine tolerance by pockel gophers. Proceedings of the Verlebrate Pest Conference 14, 87-90.

Linhart, S.B., Creekmore. T.E., Corn, J.L., Whitney, M.D., Synder, B.D., Nettles, V.F., 1993. Evaluation of baits for oral rabies vaccination of mongooses: pilot field trials in Antigua. West Indies. Journal of Wildlife Diseases 29 (2), 290-294.

Marsh, R.E.. Howard, W.E.. 1978. Vertebrate pest control manual: pocket gopher. Pest Control 46, 30-32.

Nass, R.D., Hood, G.A., Lindsey, G.D., 1971. Influence of gulch-baiting on rats in adjacent sugarcane ficlds. Journal of Wildlife Management $35,357-360$.

Savaric, P.J., Johns, B.E., Gaddis, S.E., 1992. A review of chemical and particle marking agents used for studying vertebrate pests. Proceedings of the Vertebrate Pest Conference 15, 252-257. 